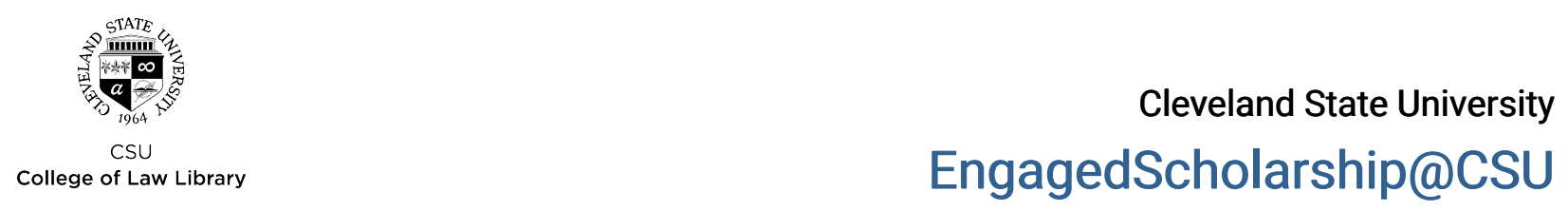

2000

\title{
Conflicts in Regulating Religious Institutions
}

\author{
Alan C. Weinstein \\ Cleveland State University, a.weinstein@csuohio.edu
}

Follow this and additional works at: https://engagedscholarship.csuohio.edu/fac_articles

Part of the First Amendment Commons, Land Use Law Commons, and the Urban Studies Commons How does access to this work benefit you? Let us know!

\section{Repository Citation}

Weinstein, Alan C., "Conflicts in Regulating Religious Institutions" (2000). Law Faculty Articles and Essays. 550.

https://engagedscholarship.csuohio.edu/fac_articles/550

This Article is brought to you for free and open access by the Faculty Scholarship at EngagedScholarship@CSU. It has been accepted for inclusion in Law Faculty Articles and Essays by an authorized administrator of EngagedScholarship@CSU. For more information, please contact research.services@law.csuohio.edu. 


\title{
Conflicts in Regulating Religious Institutions
}

\author{
By Alan C. Weinstein
}

Over the past 25 years, religious institutions have greatly increased their claims of violation of religious freedom when they are denied zoning approval or subjected to historic preservation regulations. While no one can definitively explain the causes of this increase in First Amendment challenges, it can partially be traced to recent changes in both our society and the way our political/legal system conceptualizes religious freedom.

Society has changed in a number of ways that create a greater potential for conflict. In the past, religious institutions in most American communities were the Catholic Church or "mainstream" Protestant denominations, such as Baptists, Lutherans, or Presbyterians. ${ }^{1}$ In contrast, today's fastest-growing religious groups (Mormons, Evangelical Christians, Orthodox Muslims, Hindus, Sikhs, Buddhists, and Hasidic or other Ultra-Orthodox Jews) were, until recently, either geographically isolated (Mormons in Utah and Hasidic Jews in New York City) or a minuscule presence in the U.S. until their numbers were swelled by immigrants (Sikhs, Hindus, Muslims, and Buddhists).

With this growth and dispersion of these "non-mainstream" religious groups, it is increasingly common to find one or more such groups in, or seeking to be in, any American community. This leads to land-use conflicts. The authors of a recently published study ${ }^{2}$ of all reported cases in the zoning and land-use context claim that their findings "strongly suggest that a high percentage of cases are being contested by religious groups comprising a very small percentage of the total population." Id. at 740 .

These conflicts occur in a variety of circumstances although only a small portion of the population is involved. On the one hand, the arrival of a new religious denomination-if it is small and poor-can lead to conflict if the members of the fledgling congregation seek to worship and study regularly in a private home or a rented storefront and the neighbors or local officials claim the property is not zoned for use as a house of worship. On the other hand, when a well-funded religious denomination arrives and seeks approval for a new, large house of worship-a Mormon temple or Evangelical Christian "big box church" being paradigmatic cases-neighbors or local officials may again object, citing such traditional

Alan Weinstein is a reporter for Land Use Law E Zoning Digest and an Associate Professor and Director of the Law and Public Policy Program, Cleveland State University/Cleveland Marshall School of Law.

1. Of course, larger cities, particularly those in the East and industrial Midwest, also were home to various Eastern Orthodox, African American, and Jewish houses of worship, and many Americans had some contact with one or more "non-mainstream" Protestant denominations, such as Jehovah's Witnesses or Seventh-Day Adventists.

2. "Appendix A, Discrimination Against Minority Churches in Zoning Cases," in V. Keetch and M. Richards, The Need for Legislation to Enshrine Free Exercise in the Land Use Context, 32 U.C. DAvis L. REv. 725, 736 (1999). zoning concerns as effect on property values, traffic, parking, landscaping, etc. as the basis for their opposition. Regrettably, conflict may also result from citizens' and local officials' antipathy toward, and resulting discriminatory actions against, the newly arrived denomination. ${ }^{3}$

Other factors add to this "new arrival" problem. The traditional location for houses of worship are residential neighborhoods. But here any proposed new nonresidential use is likely to be opposed by neighbors: the classic NIMBY phenomenon. In the case of newly arrived religious organizations, however, the NIMBY issue may be particularly difficult to overcome because of recent changes in the manner in which Americans worship. Previous generations attended houses of worship in their own neighborhoods, but today "religious institutions serve populations that are less and less centered in the geographic communities in which they are located." M. Stern, Zoning for Churches: Guidelines, But No Magic Formula, 7 Responsive Community No. 3 at 69, 70 (1997). Thus, the proposed house of worship is likely to be seen by its neighbors as providing few benefits-since most of them will not be members-while imposing on them the burdens associated with any more intense land-use, such as increased traffic, noise, parking difficulties, and the possibility of negative effects on property values.

Another factor that may be exacerbating land-use conflicts involving religious institutions is the escalating debate over the role of religion in American society. More conservative religious groups--perhaps best exemplified by those associated with the Christian Coalition in its heyday under Ralph Reed-havelong advocated a larger role for religion in American society. When the U.S. Supreme Court in 1990 handed down a decision ${ }^{4}$ that was seen by a broad spectrum of religious conservatives as contracting religious freedom, these groups responded by mounting a lobbying campaign asking Congress to "overturn" that decision. Their efforts resulted in the passage of the federal Religious Freedom Restoration Act, 42 U.S.C.A. \$§ $2000 \mathrm{bb}-200 \mathrm{bb}-4$ (1994) (RFRA), in 1993; however, RFRA was subsequently declared unconstitutional by

3. Professor Laycock notes that there is suspicion of, or hostility to, religious intensity. "People who are religious themselves are often hostile to unfamiliar faiths, to high intensity faiths, and to the conservative and evangelical churches associated with the 'Religious Right."' Thus in 1993, 45 percent of Americans admitted to "mostly unfavorable" or "very unfavorable" opinions of "religious fundamentalists," and 86 percent admitted to mostly or very unfavorable opinions of "members of religious cults or sects." In 1989, 30 percent of Americans said they would not like to have "religious fundamentalists" as neighbors, and 62 percent said they would not like to have "members of minority religious sects or cults" as neighbors. A desire not to have members of a minority sect as neighbors is closely related to a desire not to have the minority sect's church as a neighbor." Sec, e.g., D. Laycock, State RFRAs and Land Use Litigation, 32 U.C. DAvis L. Rev. 755, 760 (1999) (footnotes omitted).

4. Employment Division, Department of Human Resources of Oregon $v$. Smith, 494 U.S. 872 (1990). 
the U.S. Supreme Court in 1997. See City of Boerne v. Flores, 521 U.S. 507 (1997), 49 ZD 285. That decision has not put the matter to rest: The religious groups that advocated for the passage of RFRA are now lobbying both Congress and state legislatures for new legislation to exempt religious activities from regulations--including zoning and landmark preservation-that, in their view, are overly restrictive.

This article seeks to clarify where the law stands today as a context for the land-use regulation of religious institutions. It first describes how the U.S. Supreme Court has interpreted the religious freedom guarantees in the federal Constitution and how RFRA sought to alter that interpretation. In addition, how federal and state courts have interpreted religious freedom is explained in this article in the context of religious institutions ${ }^{\prime}$ legal challenges to local land-use regulations. The article concludes with an analysis of where the law stands today on major issues in the land-use regulation of religious institutions.

\section{FIRST AMENDMENT'S RELIGION CLAUSES}

The First Amendment states in relevant part: "Congress shall make no law respecting an establishment of religion, or prohibiting the free exercise thereof ..." Thus, the First Amendment's guarantee of freedom of religion addresses two distinct aspects of that freedom. First, the federal government may not take action that would effect an "establishment of religion." This is known as the Establishment Clause. Second, the federal government must not prohibit the "free exercise" of religion. This is known as the Free Exercise Clause. As with other guarantees of personal rights, the U.S. Supreme Court has ruled that the religion clauses are also applicable to state and local government through their incorporation into the due process clause of the Fourteenth Amendment. ${ }^{5}$

\section{Establishment Clause}

The Supreme Court analyzes challenges to governmental regulation that arise under the Establishment Clause under a tripartite test announced in Lemon v. Kurtzman, 403 U.S. 602 (1971). Under Lemon, a challenged government action must: (1) have a secular purpose; (2) have a primary effect that neither advances nor inhibits religion; and (3) not foster excessive government entanglement with religion. While the first two prongs of the Lemon test are utilized to evaluate challenged governmental actions that support religion, the third prong, addressing the public entanglement with religion, has been invoked to limit government regulatory programs that arguably impair religion. In recent years, although some Justices have expressed dissatisfaction with Lemon and utilized other tests for Establishment Clause claims, ${ }^{6}$ the Court has declined to overrule Lemon.

5. The "due process clause" of the Fourteenth Amendment provides: "nor shall any State deprive any person of life, liberty, or property, without due process of law." U.S. Const., amend. 14, \$1. Since 1897, the U.S. Supreme Court has ruled that various of the first 10 amendments to the Constitution, the "Bill of Rights," have been "incorporated" into the due process clause. The cases holding that the religion clauses are incorporated into the due process clause are: Cantwell v. Connecticut, 310 U.S. 296 (1940) (Free Exercise Clause) and Everson v. Board of Education, 330 U.S. 1 (1947) (Establishment Clause).

6. See, e.g., Justice O'Connor's "endorsement" test analysis in Allegheny County v. American Civil Liberties Union, 492 U.S. 573 (1989).

\section{Establishment Clause in Land-Use Context}

The Establishment Clause has been central to a number of high-profile legal and political debates over religion's role in society. These debates have focused on: How much religious expression is permissible in public schools? May publicly funded "school choice" vouchers be used for tuition at religious schools? Although the Establishment Clause has been less prominent in challenges to land-use regulations, it may be raised as a legal claim when a local government exempts religious institutions, but not other land uses, from a particular regulation. Such exemptions have most commonly involved historic preservation ordinances, but have occasionally been applied in other contexts.

The conflicting outcomes in two cases involving exemptions for schools and church-operated day care centers show the unpredictability of Establishment Clause litigation. In Cohen v. City of Des Plaines, 8 F.3d 484 (7th Cir. 1993), 46 ZD 108, cert. denied, 512 U.S. 1236 (1994), the Seventh Circuit ruled that a zoning ordinance requiring day care centers to obtain a special permit to operate in residential districts, but exempting church-run "nursery schools" from this requirement, was rationally related to a legitimate government purpose of minimizing governmental interference with religious affairs and, thus, did not violate either the Equal Protection or Establishment clauses. More recently, however, in Renzi v. Connelly School of the Holy Child, 61 F.Supp.2d 440 (D.Md. 1999), a federal trial court found an Establishment Clause violation in a Montgomery County, Maryland, zoning ordinance exempting from a special permit requirement "any private educational institution, or parochial school, which is located in a building or on premises owned or leased by any church or religious organization, the government of the United States, the State of Maryland or any agency thereof, Montgomery County or any incorporated village or town within Montgomery County." Id. at 442.

The Renzi court distinguished Cohen on the ground that, while regulating church-based day care "posed a significant risk of entangling the government in religious affairs, here, defendants do not contend that there is any danger that Montgomery County will become entangled in regulating the activity of religious education. Requiring the School to obtain a special exception would merely subject its use of the property to such basic zoning considerations as constructing facilities generally harmonious with the neighborhood and preventing excessive traffic congestion." Id. at 446. The court further stated that while the ordinance did not limit its exemption to religious schools, the vast majority of the beneficiaries of the exemption would be religious schools, and this would be an unlawful advancement of religion. Interestingly, this argument is quite similar to the reasoning employed in a recent well-publicized Ohio federal district court decision, Simmons-Harris v. Zelman, 72 F.Supp.2d 834 (N.D. Ohio 1999), striking down the Ohio school voucher program on the ground that "while both public and private schools are eligible, only private schools have chosen to participate in the Program, and the vast majority of them are parochial." Id. at 847

Exempting religious institutions from otherwise applicable historic preservation laws is also currently at issue in a case that was granted review by the California Supreme Court last May, East Bay Asian Local Development 
Corp. v. State of California, 81 Cal.Rptr.2d 908 (Cal. App.), 51 ZD 102, review granted and opinion superseded, 85 Cal.Rptr.2d 695, 977 P.2d 692 (1999). Here, a group of local governments and organizations concerned with historic preservation challenged the constitutionality of a 1994 amendment to the Government Code that effectively exempted noncommercial property owned by religious organizations from landmark designation. After a lengthy discussion of Establishment Clause and Free Exercise Clause cases, the Appeals Court upheld the amendment on the ground that "the state must have room to maneuver" between the "intrusion prohibited by the free exercise clause and [the] assistance prohibited by the establishment clause," and thus could constitutionally act to prevent local government historic preservation ordinances from impinging on the free exercise rights of religious organizations. 81 Cal.Rptr.2d at 915 . Because this opinion has been accepted for review by the California Supreme Court, however, it has no legal effect pending that court's ruling.

\section{Free Exercise Clause}

Normally, First Amendment challenges to government regulation do not involve claims that government has impermissibly singled out religious activity for regulatory treatment, but rather, that an individual or religious institution should be exempted from an otherwise valid, neutral regulation of general applicability. The U.S. Supreme Court's first decision on the Free Exercise Clause, Reynolds $v$. United States, 98 U.S. 145 (1878), affirming the bigamy conviction of a Mormon, essentially denied the concept that a general governmental regulatory scheme could ever violate the Free Exercise Clause by crafting a dichotomy between religious belief and religious practice. The Court said that while laws "cannot interfere with mere religious belief and opinions, they may with practices." Id. at 166. For the next 90 years, the Court declined to sustain a claim that a general regulatory scheme violated the Free Exercise Clause.

The modern era of Free Exercise Clause interpretation can be traced to the Court's 1963 decision in Sherbert $v$. Werner, 374 U.S. 398 (1963), upholding a free exercise challenge to an unemployment compensation law that effectively penalized the plaintiff's refusal to work on her Sabbath. The Sherbert decision interpreted the Free Exercise Clause as requiring an exemption from a government regulation that significantly burdens religious practice unless the regulation could be justified by a compelling governmental interest and was the least restrictive means of achieving that interest. The Court reaffirmed Sherbert's principles nine years later in Wisconsin v. Yoder, 406 U.S. 205 (1972), holding that Wisconsin's law criminalizing the failure to obey the state's mandatory school attendance requirement could not be enforced against Amish families who refused to send their children to school beyond the eighth grade. But Yoder proved to be the high watermark for free exercise exemptions: Following Yoder, the Court rejected every free exercise challenge to a general governmental regulation, except for those claims based on a denial of unemployment compensation benefits that were governed directly by Sherbert. Despite the Court's failure to uphold claims for exemption outside the unemployment context after Yoder, Sherbert's principles were not dead. They were applied by state and lower federal courts, and state and local governments would often craft religious exemptions to conform to their perception of what Sherbert required.

\section{Reinterpretation of Free Exercise in Smith}

The Supreme Court's 1990 decision in Employment Division, Department of Human Resources of Oregon v. Smith, 494 U.S. 872 (1990), dramatically revised its interpretation of the Free Exercise Clause. In Smith, a sharply divided Court ${ }^{7}$ denied the free exercise claim of two Oregon state employees who had been denied unemployment benefits after they were fired as drug and alcohol counselors because the state viewed their religiously motivated peyote smoking as work-related misconduct. In denying their claim, the Court abandoned Sherbert's "compelling interest" test, holding that "the right of free exercise does not relieve an individual of the obligation to comply with a 'valid and neutral law of general applicability on the ground that the law proscribes (or prescribes) conduct that his religion prescribes (or proscribes).'" Stated another way, "an individual's religious beliefs [do not] excuse him from compliance with an otherwise valid law prohibiting conduct that the State is free to regulate." Id. at 879 . In the Court's view, striking a balance between protection of religious practices and the requirements imposed by neutral laws of general application was a task for legislatures, not courts.

Three years later, in Church of the Lukumi Babalu Aye, Inc. v. City of Hialeah, 508 U.S. 520 (1993), the Court made clear that Smith did not apply to laws that are "non-neutral" because their object is to infringe upon or restrict practices based on their religious motivation. In Babalu Aye, which dealt with a group of ordinances that restricted the practice of ritual animal sacrifice by the Santeria religion-an amalgam of traditional African beliefs and Roman Catholicism - the Court ruled unanimously that a law targeting religion may be upheld only if justified by a compelling governmental interest and narrowly tailored to advance that interest. ${ }^{8}$ The significance of the Babalu Aye decision lay in the willingness of the Court to discount the self-serving arguments of municipal officials regarding the "neutrality" of the anti-Santerian ordinances. The case thus sent a strong signal to the lower courts that the Smith decision, which had been widely criticized on the ground that it would lead to an erosion of religious liberty for "non-mainstream" religions, should not be read to permit the targeting of religious practices under the guise of a purportedly general and religiously neutral ordinance.

7. Justice Scalia wrote the majority opinion, which was joined by Justices Rehnquist, White, Stevens, and Kennedy. Justice $\mathrm{O}^{\prime}$ Connor concurred in the judgment, but wrote a separate opinion, which Justices Brennan, Marshall, and Blackmun joined in part; Justice Blackmun wrote a dissenting opinion, which Justices Brennan and Marshall joined.

8. The ordinances totally barred ritual animal sacrifice and prohibited the "slaughter" of animals outside of areas zoned for slaughterhouses, but provided an exemption for kosher slaughter. The Court, finding the record replete with evidence of hostility towards the Santerian's practice of ritual slaughter, concluded that suppression of such sacrifices was the object of the ordinances, thus requiring that they be justified by a compelling governmental interest. The Court then found that the city's asserted interests in protecting the public health and preventing cruelty to animals could be addressed by restrictions short of a total ban on ritual slaughter. 508 U.S. 520, 537-38. 


\section{RELIGIOUS FREEDOM RESTORATION ACT}

The hostility of a broad spectrum of religious and political groups to the Smith case, which was not abated in the least by the Babalu Aye decision, led to a concerted effort aimed at Congressional action to "restore" the religious protections that Smith had removed. The effort was astonishingly successful: The Religious Freedom Restoration Act (RFRA) was passed unanimously in the House of Representatives and drew only three negative votes in the Senate. President Clinton described the act's signing ceremony as having "a majestic quality" because of the central role that religion played in American life. Substantively, RFRA stated that Smith "virtually eliminated the requirement that the government justify burdens on religious exercise imposed by laws neutral toward religion," 42 U.S.C.A. $\$ 2000 b b(a)$ (1994), and sought to restore that requirement by legislatively mandating that government shall not substantially burden a person's exercise of religion, even if the burden results from a rule of general applicability, "unless (1) it is in furtherance of a compelling governmental interest; and (2) is the least restrictive means of furthering that compelling governmental interest." 42 U.S.C.A. $\$ 2000$ bb (a)\&(b) (1994).

Although RFRA resulted in hundreds of lawsuits before it was struck down in 1997, less than a dozen RFRA cases involved claims based on land-use regulations. ${ }^{9}$ Further, a number of cases challenging such regulations during this period ignored RFRA, and relied solely on claims that the governmental action violated federal and/or state constitutional guarantees of religious freedom. ${ }^{10}$ In all, only a handful of cases successfully challenged landmark or land-use regulations under RFRA, one of them being the decision in Flores v. City of Boerne, 73 F.3d 1352 (5th Cir. 1996), 49 ZD 145, that was subsequently reversed by the Supreme Court.

The lower court decisions involving RFRA challenges to land-use regulations yielded mixed results. For example, several courts found that RFRA barred enforcement of zoning restrictions on religious institutions that sought to establish homeless shelters or food programs in residential areas. ${ }^{11}$ However, in Daytona Rescue Mission, Inc. v. City of Daytona Beach, 885 F.Supp. 1554 (M.D. Fla. 1995), 48 ZD 2, a Florida federal district court rejected a claim that RFRA barred the application of location restrictions to a homeless shelter and food bank proposed to be housed in a church. The court found that "the City's interest in regulating homeless shelters and food banks is a compelling interest and that [the zoning] code furthers that interest in the least restrictive means," thus upholding the city under the First Amendment

9. Most RFRA cases were filed by prison inmates who claimed that various prison rules violated their religious freedoms. The overwhelming majority of these claims were found to be without merit.

10. Depending on the case, these failures to raise a RFRA claim could be explained by anything from good legal strategy (e.g., there were favorable precedents under the state constitution, or concerns about RFRA's constitutionality or the plaintiff had a weak case and did not want to set a "bad" precedent on a RFRA claim) to malpractice ("What's RFRA?").

11. See Stuart Circle Parish v. Board of Zoning Appeals of the City of Richmond, 946 F.Supp. 1225 (E.D. Va. 1996); Western Presbyterian Church v. District of Columbia, 862 F.Supp. 538 (D.D.C. 1994), 47 ZD 82; Jesus Center v. Farmington Hills Zoning Bd. of Appeals, 544 N.W.2d 698 (Mich. App. 1996), 48 ZD 229. analysis that predated Smith. Id. at 1560.

In other land-use cases decided under RFRA, courts: denied a claim that RFRA barred the application of parking requirements to religious institutions; ${ }^{12}$ held that RFRA does not apply to uses that constitute a nuisance, in this instance a massive display of Christmas lights that created traffic jams and other problems in a residential neighborhood, ${ }_{;}^{13}$ denied a preliminary injunction to plaintiffs claiming that RFRA barred the need for a special permit for a Wiccan Church in a residential district, ${ }^{14}$ and declared RFRA to be an unconstitutional violation of separation of powers. See Keelerv. Cumberland, 928 F.Supp. 591 (D.Md. 1996).

As can be seen from this brief description of cases decided under RFRA, the act had relatively little impact on land-use regulation of religious institutions in its three and a half years of existence. RFRA's legislative sponsors claimed that the act was needed, in part, to blunt the harmful effects of land-use regulations, ${ }^{15}$ but the validity of this claim is certainly called into question by the fact that there were only a handful of RFRA challenges to land-use regulations. Moreover, RFRA challenges were generally unsuccessful, aside from the three cases in which courts ruled that RFRA required an exemption from zoning laws that would otherwise prohibit a religious institution from operating a food or shelter program for the homeless. See note 11, supra. And even in this category of cases, Daytona Rescue Mission rejected a RFRA challenge and Jesus Center came under sharp criticism. See, Mary J. Dwyer, Note, Oops! You Missed a Step: The Court Stumbles on the Substantial-Burden Threshold in Jesus Center v. Farmington Hills Zoning Board of Appeals, 14 Cooley L. Rev. 121 (1997).

\section{The Demise of RFRA}

The dispute in City of Boerne v. Flores, 521 U.S. 507 (1997), arose the same year RFRA was enacted. The city, a booming suburb of San Antonio, Texas, denied St. Peter's Catholic Church a building permit for a proposed addition because the church was located partially in a historic district. The church, built in the mission style in 1923, had begun planning in 1990 for the addition, needed to accommodate its rapidly growing congregation. At about the same time, the city council authorized the city's Historic Landmark Commission to prepare a historic preservation plan for the city. Under that plan, the church facade, but not the rest of the structure, fell within the historic district, leading to the denial of the church's request for a permit that would involve demolition of the facade. The Archbishop of San Antonio, P.F. Flores, then sued the city in federal district court, arguing that the permit denial violated RFRA. The district court denied the claim, holding that RFRA was unconstitutional

12. Germantown Seventh-Day Adventist Church v. Philadelphia, 1994 WL 470191 (E.D. Pa.).

13. Osborne v. Power, 890 S.W.2d 570 (Ark. 1994) (citing dictum in Western Presbyterian).

14. Church of Iron Oak v. Palm Bay, 868 F.Supp. 1361 (M.D. Fla. 1994).

15. This claim they reiterate today before both the U.S. Congress and state legislatures. See, e.g. Douglas Laycock, State RFRAs and Land Use Regulation, 32 U.C. DAvIS L. Rev. 755 (1999). 


\section{Commentary}

because it usurped the power of the judiciary "to say what the law is." 877 F.Supp. 355 (W.D. Tex. 1995). The Fifth Circuit Court of Appeals reversed, upholding RFRA, ${ }^{16}$ and the U.S. Supreme Court agreed to hear the case.

In City of Boerne, the Court ruled 6-3 that RFRA was unconstitutional. Although the case yielded five separate opinions, Justice Kennedy's majority opinion found that the statute was unconstitutional because it exceeded the powers that Congress had been granted under the enforcement clause of the Fourteenth Amendment. ${ }^{17}$ Justice Stevens, in a separate concurring opinion, argued that RFRA also violated the Establishment Clause of the First Amendment because it granted a governmental preference for religion, noting explicitly that had the historic structure been "a museum or art gallery" rather than a church, it would not be eligible for an exemption from the city's landmark ordinance.

\section{Developments Since Boerne}

The Court's rejection of RFRA in Boerne was not the last word on either the immediate dispute or the larger issues in the case. After the case was remanded back to the trial court for a decision based on $S m i t h{ }^{18}$ the church and the city council agreed to a settlement that would add a 750-seat auditorium to the back of the existing church while retaining almost 80 percent of the original structure. The city's Historical Landmark Commission remained opposed to the demolition of any portion of the landmarked church, however, and, in September 1997, refused to take action on the church's request for a demolition permit. The next day, the trial judge dismissed the lawsuit, refusing to give the parties any more time to finalize the settlement agreement. The matter was finally concluded the following month when the city council authorized the church to proceed with the demolition. Construction of the new facility was finished in early 1999.

The larger issues in this case will not be resolved so easily or expeditiously. Following the Supreme Court's ruling,

16. Flores v. City of Boerne, 73 F.3d 1352 (5th Cir. 1996) (holding RFRA does not violate the separation of powers and that the enforcement clause of the Fourteenth Amendment empowers Congress to legislate acts such as RFRA to scrutinize statutes which burden an individual's free exercise of religion).

17. Justice Kennedy's opinion, which was joined by Chief Justice Rehnquist and Justices Stevens, Thomas, and Ginsburg, with Justice Scalia joining in all but a minor portion, focused on whether RFRA was a proper exercise of the enforcement power granted to the Congress under Section 5 of the Fourteenth Amendment-"The Congress shall have power to enforce, by appropriate legislation, the provision of this article"-since "Congress relied on its Fourteenth Amendment enforcement power in enacting the most far reaching and substantial of RFRA's provisions, those which impose its requirements on the states." 521 U.S. 507, 517. Kennedy argued that because the act was so farreaching-applying "at every level of government, displacing laws and prohibiting official actions of almost every description and regardless of subject matter," Id. at 532, and imposed strict scrutiny-" the most demanding test known to constitutional law"-Id. at 534, if a claimant under the act could demonstrate a substantial burden, the act "is so out of proportion to a supposed remedial or preventive object that it cannot be understood as responsive to, or designed to prevent, unconstitutional behavior. It appears, instead, to attempt a substantive change in constitutional protections." Id. at 532. Thus, Kennedy concluded, RFRA contradicted vital principles necessary to maintain the separation of powers and was unconstitutional.

18. Flores v. City of Boerne, 119 F.3d 341 (5th Cir. 1997). various religious and political groups brought several different "religious freedom" proposals to Congress. What has emerged is the Religious Liberty Protection Act of 1999, H.R. 1691, approved by the House in July 1999. That act, in brief, is another attempt to restore the "compelling interest" standard for general laws that are determined to burden the free exercise of religion. State legislatures have also been the target of campaigns to enact "religious freedom" legislation, a number of which have been successful, ${ }^{19}$ with legislation awaiting action in Colorado, Missouri, and Oregon. There have also been some defeats, however, with legislation vetoed in New Mexico and sponsors withdrawing their bills in California and Maryland.

Given the limited impact of RFRA on the outcome of challenges to land-use regulations, it is certainly questionable whether this new state legislation will have any significant effect. In the first reported case involving a "state RFRA," City of Chicago Heights v. Living Word Outreach Full Gospel Church and Ministries, Inc., 707 N.E.2d 53, 51 ZD 160 (Ill App. 1999), appeal allowed, 184 Ill. 2d 554, 714 N.E.2d 525 (1999), an Illinois appellate court upheld the city's requirement that prohibited any religious group from establishing a house of worship in a B-2 commercial zone until it obtained a special use permit. This decision is noteworthy, both because the case was decided under the pre-Smith compelling interest test, as required by the Illinois Religious Freedom Restoration Act, Ill. Pub. Act 98-806 (December 2, 1998), and because the Illinois Supreme Court agreed in June 1999 to hear an appeal of the decision.

\section{WHERE ARE WE NOW?}

\section{Zoning Houses of Worship}

There are three basic approaches to cases involving challenges to zoning regulations that would have the effect of prohibiting a house of worship at a particular location. A minority of state courts, exemplified by California, apply a due process analysis to the zoning of a house of worship and treat such uses no differently than any other land use and thus presume that the prohibition is justified unless the religious institution can prove that it is not. In the majority of states, with New York being the leading example, courts apply a due process analysis that places houses of worship in a preferred category so that it is the local government that bears the burden of justifying its prohibition. The federal courts, in contrast, apply a First Amendment balancing test to judge the constitutionality of a zoning prohibition. Each of these approaches is explained in greater detail below.

\section{State Courts}

State courts historically approached zoning restrictions on houses of worship under a substantive due process, rather than First Amendment, analysis, the traditional "majority" position being that the exclusion of houses of worship from residential neighborhoods is a violation of substantive due process. See, e.g., Jewish Reconstructionist Synagogue of North Shore, Inc. v. Incorporated Village of Roslyn Harbor, 342 N.E.2d

19. As of late 1999, the following states had enacted a "religious freedom" statute: Alabama (constitutional amendment approved by public referendum), Arizona, Connecticut, Florida, Illinois, Rhode Island, South Carolina, and Texas; the last, however, containing an exemption for land-use regulation. 
534 (N.Y. 1975), 28 ZD 361, cert. denied, 426 U.S. 950 (1976). The traditional "minority" position held that such exclusion is a valid exercise of the police power so long as houses of worship are not totally excluded from a community. See, e.g., Corporation of Presiding Bishop of Church of Jesus Christ of Latter-day Saints v. City of Porterville, 203 P.2d 823, 1 ZD 39 (Cal. App. 1949), appeal dismissed, 338 U.S. 805 (1949).

In recent years, however, there have been two discernible trends in the state courts. First, there has been some erosion of the traditional "majority" position. For example, in City of Colorado Springs v. Blanche, 761 P.2d 212 (Colo. 1988), the Colorado Supreme Court overruled City of Englewood $v$. Apostolic Christian Church, 362 P.2d 172 (Colo. 1961), 41 ZD 169 , which held that an ordinance requiring a conditional use permit for churches to locate in single- and two-family districts was unconstitutional as a blanket exclusion of churches from those districts. In Colorado Springs, the court stated that it was joining "the majority of jurisdictions" that make the right of a church to locate in a particular district permissive rather than absolute. 761 P.2d at 216-17. Even in New York, the leading "majority" jurisdiction, the preferred position of religious institutions has become less clear in recent years. See Cornell University v. Bagnardi, 503 N.E.2d 509, 514 (N.Y. 1986), 39 ZD 193 (stating "[t]here is simply no conclusive presumption that any religious or educational use automatically outweighs its ill effects").

Second, there has been a movement in some state courts towards applying an analysis based on the First Amendment, rather than substantive due process, in cases involving regulation, rather than outright prohibition, of religious institutions. For example, in Korean Buddhist Dae Won Sa Temple v. Sullivan, 953 P.2d 1315 (Haw. 1998), 51 ZD 8, the Hawaii Supreme Court upheld a height limitation applied to the plaintiff's house of worship after finding that the regulation did not substantially burden the free exercise rights of the worshipers. Several other courts have also found that various zoning regulations did not impermissibly infringe upon the free exercise of religion. ${ }^{20}$

\section{Federal Courts}

Prior to 1983, no federal Court of Appeals had considered a case involving the zoning of religious institutions. In that year, both the Sixth Circuit, in Lakewood, Ohio, Congregation of Jehovah's Witnesses v. City of Lakewood, 699 F.2d 303 (6th Cir. 1983) and the Eleventh Circuit, in Grosz v. City of Miami Beach, 721 F.2d 729 (11th Cir. 1983), 36 ZD 88, upheld zoning regulations against First Amendment challenges, using different variations of a balancing test that weighed the competing interests of municipal regulation and freedom of religion.

In Lakewood, where the zoning code restricted new houses of worship to an area comprising approximately 10 percent

20. See, e.g: Grace Community Church v. Town of Bethel, 622 A.2d 591 (Conn. App. 1993), 45 ZD 343 (applying First Amendment analysis in upholding special permit requirement for churches); Bethel Lutheran Church v. Village of Morton, 559 N.E.2d 533 (Ill.App. 1990) (using First Amendment analysis to uphold the imposition of an enrollment cap on a parochial school); and Macedonian Orthodox Church v. Planning Board of the Township of Randolph, 636 A.2d 96 (N.J. Super. 1994), 46 ZD 327 (finding no First Amendment issue in ordinance requiring a special use permit before a church could construct an accessory building). of the city, the Sixth Circuit used a two-step inquiry, first evaluating the nature of the religious observance at stake and then the nature of the burden that the municipality sought to place on the religious observance. The court found the only burden on religious observance posed by the ordinance was financial: The congregation could worship as it pleased, but was restricted in locating its proposed sanctuary. The court distinguished this minor burden from an ordinance that forced the congregation to forego religious observance through financial or criminal penalties or by placing burdensome taxes on the exercise of religious beliefs. Since the court found no restriction of First Amendment rights, it determined that the municipality was free to regulate the location of churches in a reasonable manner to maintain the residential character of certain neighborhoods.

In Grosz, an elderly Orthodox Jewish rabbi converted his garage into a sanctuary for religious worship and as many as 50 congregants would attend religious services on occasion. Religious uses were not permitted in this zone, but were allowed in at least 50 percent of the residential zones, including an area four blocks from the rabbi's home. The Eleventh Circuit employed a slightly different analysis than had the Sixth in Lakewood, considering two threshold tests before balancing the competing interests of the municipality and the First Amendment. First, the court asked whether the government sought to regulate religious beliefs or opinions rather than merely placing a burden on religious conduct. While the government may never regulate religious beliefs, the First Amendment does not absolutely prohibit government regulation that burdens religious practices. Second, the ordinance must have both a secular purpose and effect. Only if a government regulation passes both of these threshold tests should a court balance the burden on the city's legitimate interests in maintaining its zoning objectives against the burden on the plaintiff's right to free exercise of religion. Given the facts in this case, the court found that the ordinance passed both threshold tests and that the city's substantial interests in maintaining certain wholly residential zones free of the noise and crowds associated with religious worship did not unduly burden freedom of religion since more than half the city was available for religious institutions.

Since 1983, the majority of federal courts that have considered religious challenges to zoning ordinances have upheld those ordinances, with most applying the Grosz analysis. ${ }^{21}$ But in Islamic Center of Mississippi, Inc. v. City of Starkville, 840 F.2d 293 (5th Cir. 1988), 40 ZD 201, the Fifth Circuit found that an ordinance, applied to deny a special permit for establishment of a mosque at numerous proposed sites, placed more than an incidental burden on the free exercise of religion because it had the effect of forcing a group of rela-

21. See, e.g., Mount Elliott Cemetery Ass'n v. City of Troy, 171 F.3d 403 (6th Cir. 1999), 51 ZD 223 (holding that a city's denial of a rezoning request for property planned for a Catholic cemetery did not violate the landowner's right to free exercise of religion because zoning ordinance was a neutral law of general applicability and the request was denied because of various factors-e.g. insufficient buffer areas, traffic congestion, etc.-related to the use of the property); and Christ College, Inc. v. Board of Supervisors, 944 F.2d 901 (4th Cir. 1991), cert. denied, 502 U.S. 1094 (1992) (holding that zoning regulation, which prohibited the church from building a parochial school in a residential zone without a special exception, was not a significant burden on the church's religious rights). 
tively poor university students to establish their mosque at sites that were reasonably accessible only by automobile. ${ }^{22}$ Subsequently, in Church of Jesus Christ of Latter-day Saints $v$. Jefferson County, 741 F.Supp. 1522 (N.D. Ala. 1990), ${ }^{23} 42$ ZD 279, a federal district court relied on both Grosz and Islamic Center to strike down the county's procedure for obtaining a rezoning to allow development of land for churches, which permitted decisions to be determined on the basis of the neighborhood's willingness to accept a church. The court termed this "a thin reed upon which to base the exercise of religious freedom," and suggested that the answer was to set aside areas zoned for churches as of right or to set solely objective standards for rezonings. $I d$. at 1534.

\section{HISTORIC PRESERVATION OF HOUSES OF WORSHIP}

Several cases have considered either federal or state constitutional challenges to the application of historic preservation ordinances to churches. While state supreme courts in Washington and Massachusetts have each invalidated the designation of one or more churches as a landmark, and a Maryland federal district court held that a landmark ordinance was unconstitutional, the Second Circuit Court of Appeals has upheld such designations.

\section{State Cases}

In First Covenant Church v. City of Seattle, 787 P.2d 1352 (Wash. 1990), 42 ZD 385, vacated and remanded, 499 U.S. 901 (1991), holding reinstated, 120 Wash. 2d 203, 840 P.2d 174 (1992), 45 ZD 235, the Washington Supreme Court found that mere landmark designation of a church's exterior states a constitutional violation under both the federal and state constitutions. After its designation as a landmark in 1985, the First Covenant Church sued the city of Seattle, seeking a declaratory judgment that landmark designation of churches was unconstitutional and that the enactment of an ordinance specifically designating First Covenant Church a landmark was void. The trial court held that the landmarks ordinance was properly applied to churches and that until the city took some action under the landmarks ordinance that burdened the church-i.e., something beyond mere designation as a landmark - the church's claim that the landmarks ordinance violated its rights of religious freedom was premature. 787 P.2d at 1353-1354.

The Washington Supreme Court reversed the trial court on both issues; however, that decision was rendered prior to the U.S. Supreme Court's landmark ruling in Smith. Subsequently, after granting certiorari, the U.S. Supreme Court vacated the judgment and remanded to the Washington Supreme Court for further consideration in light of Smith. On remand, the Washington court distinguished First Covenant from Smith on the ground that Seattle's landmark ordinance was not a neutral law of general application because it referred specifically to religion and

22. The court also found that the city did not treat all religious institutions that applied for special exceptions alike and could advance no rational basis other than neighborhood opposition to show why the exception granted to all other religious centers was denied the Islamic Center.

23. See also 721 F.Supp. 1212 (N.D. Ala. 1989). targeted specific structures for landmark designation. The Washington Court then insulated its decision from further federal court review by holding, as an independent ground for its decision, that the ordinance was invalid under the state constitution. ${ }^{24}$ In subsequent decisions, the Washington Court held that mere designation of a church as a landmark violated religious freedom because it might pose a barrier should the church seek to sell the property-First United Methodist Church v. Hearing Examiner, 129 Wash.2d 238, 916 P.2d 374 (1996)_and that a demolition permit ordinance, which had potential to cause a 14month delay in plans to demolish a Catholic school building and construct a pastoral center, violated the free exercise of religion guaranteed in the state constitution: Munns $v$. Martin, 131 Wash.2d 192, 930 P.2d 318 (1997).

The Massachusetts case, Society of Jesus v. Boston Landmarks Commission, 409 Mass. 38, 564 N.E.2d 571 (1990), is somewhat unusual in that it involved designation of portions of the church's interior as well as its exterior. The Jesuits sued, claiming that the designation of the interior of the church as a landmark violated provisions in both the federal and state constitutions. The Supreme Judicial Court of Massachusetts ruled that the landmark designation violated the state constitution," ${ }^{25}$ arguing that "[t]he configuration of the church interior is so freighted with religious meaning that it must be considered part and parcel of the Jesuits' religious worship." Id. at 573. The court also ruled that the government interest in historic preservation, although worthwhile, was not sufficiently compelling to justify a restraint on the free exercise of religion. $I d$. at 574 .

\section{Federal Courts}

On the same day that the Supreme Court vacated the judgment in First Covenant and remanded that case to the Washington court, it declined to review St. Bartholomew's Church $v$. City of New York, 914 F.2d 348 (2d Cir. 1990), cert. denied, 499 U.S. 905 (1991), where the Second Circuit had relied on Smith to uphold the New York Landmarks Law against free exercise and takings claims. In St. Bartholomew's, a landmarked church sought approval to demolish its seven-story "community house" adjacent to the sanctuary and erect a 59-story office tower in its place. When this first request was denied as an inappropriate alteration, the church filed a second application, scaling down its proposed tower to 47 stories. When this application was also denied, the church filed a third application under a "hardship exception," claiming that the commission should issue a certificate of appropriateness for the 47-story tower because the community house was inadequate and the church needed the revenues it would obtain from the new building both to maintain its sanctuary and expand its social welfare programs. After several lengthy public hearings and open executive sessions, the commis-

24. Article 1 , section 11 of the Washington Constitution provides that "[a]bsolute freedom of conscience in all matters of religious ... worship ... shall be guaranteed to every individual."

25. Article Two of the Massachusetts Constitution provides, in part: "[N]o subject shall be hurt, molested, or restrained in his person, liberty, or estate, for worshipping God in the manner and season most agreeable to the dictates of his own conscience; or for his religious profession or sentiments; provided he doth not disturb the public peace, or obstruct others in their religious worship." 
sion denied the application because the church had failed to prove the necessary hardship.

The church then challenged the Landmarks Law, claiming that it violated both the Establishment and Free Exercise clauses of the First Amendment by excessively burdening the practice of religion and entangling the government in religious affairs. The federal district court upheld the commission, grounding its ruling on the New York Court of Appeals "charitable purpose" test. ${ }^{26}$ On appeal, the Second Circuit affirmed, but declined to apply the "charitable purpose" test. Relying instead on a number of Supreme Court Free Exercise cases-including Smith, which was decided after the district court decision-the Court of Appeals found that "the Landmarks Law is a valid, neutral law of general applicability" and agreed with the district court that the church failed to prove that it cannot continue its religious practices in its existing facilities. ${ }^{27}$

In contrast to the Second Circuit's ruling in St. Bartholomew's, in Keeler v. Cumberland, 940 F.Supp. 879 (D.Md. 1996), a Maryland federal district court ruled that a local landmark law was not a "neutral law of general applicability" under Smith, due to its variance and hardship provisions. Applying a compelling governmental interest test, the state court found that a denial of a permit to demolish a landmarked monastery violated the federal and state constitutions. Keeler illustrates two related points. First, that the Smith analysis need not prove fatal to all Free Exercise challenges because of the potential for flexibility in the application of the Smith analysis, both in deciding whether the challenged regulation is a "neutral law of general applicability" and, if it is not, whether the governmental interest asserted is "compelling." Second, that same potential for flexibility makes it difficult to predict the outcomes of such cases.

\section{Contrast of Federal and State Courts in Landmarking Cases}

As noted above, on the same day the U.S. Supreme Court vacated the judgment in First Covenant and remanded the case to the Washington Supreme Court for reconsideration in light of Smith, it declined to review the Second Circuit's decision in St. Bartholomew's which had relied on Smith. These actions signal that the Court, when it last faced the issue, did not view landmark laws as suspect under the federal constitution merely because they apply to religious institutions. Thus, a religious institution will not be excused from complying with landmark laws, on federal constitutional grounds, unless it can prove that meeting those requirements leaves it unable to carry out its religious mission.

While this latest statement by the Supreme Court will guide how challenges to landmark laws are decided under the federal constitution, it does not bar state courts from finding greater protection for religious institutions under

26. Under that test, there is a violation where the landmark designation would prevent or seriously interfere with the carrying out of the charitable purpose of the institution. See A. Weinstein, The Myth of Ministry vs. Mortar: A Legal Policy Analysis of Landmark Designation of Religious Institutions, 65 TEMPLE L. Rev. 91, 116-123 (1992).

27. Id. at 354-356. In a footnote, the Second Circuit also agreed that the district court had been correct to dismiss the church's claim that the landmarks law violated the Establishment Clause. Id. at 356, n. 4. provisions of their state constitutions. In this regard, the Washington decisions have far broader implications in terms of a possible divergence between federal and state jurisprudence on free exercise claims in historic preservation cases than does the Massachusetts Court's decision in Society of Jesus. First, the Massachusetts decision involved landmark designation of the church's interior and few ordinances authorize such designation, likely because landmark commissions recognize that such designations raise significant First Amendment issues. ${ }^{28}$ Further, the "Free Exercise Clause" of the Massachusetts constitution is stated in far broader terms ${ }^{29}$ than the corresponding clause in the federal constitution and has a legislative history that emphasizes its role in guaranteeing freedom of choice as to manner of worship. See Society of Jesus, 564 N.E.2d at 572-573. Thus, while it is true that many state constitutions guarantee freedom of religion in terms far broader than those in the First Amendment, few, if any, feature the combination of broadly protective terminology and legislative history found in Massachusetts. ${ }^{30}$

The potential reach of the Washington decisions stems from the fact that the Washington Supreme Court, prior to its decision in First Covenant on remand, had applied the compelling interest test by relying on federal Free Exercise cases and had never suggested that its state free exercise provision had an existence independent of the First Amendment. SeeS. Parsell, Note, Revitalization of the Free Exercise of Religion Under State Constitutions: A Response to Employment Division v. Smith, 68 Notre Dame L. Rev. 747, 759 (1993). Thus, by recognizing the independence of the free exercise clause in the state constitution, the Washington Court offers guidance to any state seeking authority by which to retain the compelling state interest test.

\section{CONCLUSION}

In the case of religious freedom challenges to land-use regulation, the question may not so much be "Where Are We?" as "Where Are You?" Similar religious freedom claims may have very different outcomes depending on the jurisdiction or court in which they are brought. In contrast to the federal courts-where religious freedom challenges have rarely been successful, absent blatant discrimination, including challenges brought under the "compelling interest" test during both the pre-Smith and RFRA eras-the success of a religious freedom challenge in state court has always depended in large part on whether that state had adopted the "majority" (preferential treatment) or "minority" (no preferential treatment) view of the substantive due process standard to be applied to such challenges. Further, the differing treatment of "religious freedom" challenges to land-use regulation in state courts is

28. See, A. Carmella, Houses of Worship and Religious Liberty: Constitutional Limits to Landmark Preservation and Architectural Review, 36 VILL. L. REv. 401 (1991) (critiquing the relationship between architecture and theology).

\section{See note 25 , supra.}

30. For example, the parallel provision of the Washington Constitution, Article 1, section 11, provides that "[a]bsolute freedom of conscience in all matters of religious ... worship ... shall be guaranteed to every individual." 


\section{Commentary}

now also being affected by the enactment of state RFRAs and whether, like Texas, it is a state RFRA that exempts land-use regulation from its effect.

We are clearly in the midst of a dynamic environmentsocially, politically, and legally-regarding the conflict between religious institutions and land-use regulation. Regrettably, elements on both sides at times have advocated extreme positions. Some religious groups claim that their right to choose when and where they assemble for worship is almost absolute and that government may never lawfully landmark a property devoted to religious use if the congregation objects. Some local officials and citizens groups argue that "religious freedom" should apply only to beliefs and practices, and thus decisions about where a house of worship may locate or whether it should be landmarked involve nothing more than property rights and so a church should be treated no differently than a discount store or movie theater.

There is surely room for accommodation between these extremes. Religious worship should not be allowed to occur wherever and whenever a congregation chooses with scant regard for the negative effects imposed on neighbors and the surrounding community. Likewise, a request for permission to construct or occupy a site for religious worship should not be equated with permission to construct a commercial building. 


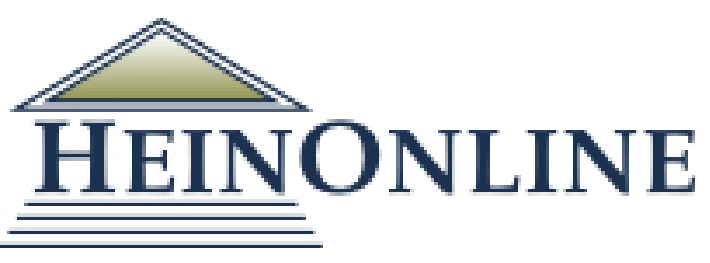

Content downloaded/printed from

HeinOnline

Wed Oct 16 14:48:57 2019

Citations:

Bluebook 20th ed.

Alan C. Weinstein, Conflicts in Regulating Religious Institutions, 52 Land Use L. \& Zoning Dig. 3 (2000).

ALWD 6th ed.

Alan C. Weinstein, Conflicts in Regulating Religious Institutions, 52 Land Use L. \& Zoning Dig. 3 (2000).

APA 6th ed.

Weinstein, A. C. (2000). Conflicts in regulating religious institutions. Land Use Law Zoning Digest, 52(3), 3-11.

Chicago 7th ed.

Alan C. Weinstein, "Conflicts in Regulating Religious Institutions," Land Use Law \& Zoning Digest 52, no. 3 (March 2000): 3-11

McGill Guide 9th ed.

Alan C Weinstein, "Conflicts in Regulating Religious Institutions" (2000) 52:3 L\& Use L \& Zoning Digest 3.

MLA 8th ed.

Weinstein, Alan C. "Conflicts in Regulating Religious Institutions." Land Use Law \& Zoning Digest, vol. 52, no. 3, March 2000, p. 3-11. HeinOnline.

OSCOLA 4th ed.

Alan C Weinstein, 'Conflicts in Regulating Religious Institutions' (2000) 52 Land Use

L \& Zoning Dig 3

Provided by:

Cleveland-Marshall College of Law Library

-- Your use of this HeinOnline PDF indicates your acceptance of HeinOnline's Terms and Conditions of the license agreement available at https://heinonline.org/HOL/License

-- The search text of this PDF is generated from uncorrected OCR text.

-- To obtain permission to use this article beyond the scope of your license, please use: Copyright Information

Use QR Code reader to send PDF to your smartphone or tablet device

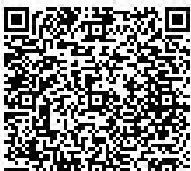

